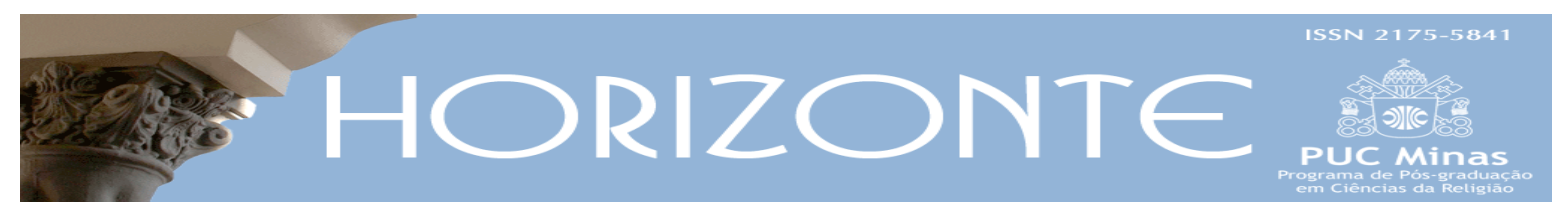

Dossiê: Religião, Direitos Humanos e Direitos da Natureza - Artigo Original (c) (i) DOI - 10.5752/P.2175-5841.2017v15n47p697

\title{
Teologia, Direitos Humanos e Pensamento Decolonial
}

\author{
Theology, Human Rights and Decolonial thinking
}

\author{
Carlos Alberto Motta Cunha*
}

\begin{abstract}
Resumo
No livro Se Deus fosse um ativista dos direitos humanos, Boaventura de Sousa Santos defende a ideia de que o diálogo entre os direitos humanos e as teologias progressistas é uma boa possibilidade para o desenvolvimento de práticas interculturais e emancipadoras (2014, p.113). Como a teologia pode contribuir para a reconstrução da humanidade dos direitos humanos? A contemporaneidade com toda a sua complexidade reclama a construção de uma teologia consciente da pluralidade cultural e religiosa capaz de abraçar dentro de seu horizonte as experiências sócio-religiosas do conjunto da humanidade. A tarefa de decolonizar a teologia, e/ou de recriar seu conteúdo, não implica apenas uma novidade no objeto, mas exige também uma novidade no sujeito, ou seja, faz-se necessário um novo tipo de teólogo, com um novo tipo de consciência e postura diante da atualidade. Na busca por respostas aproximativas, este artigo faz apontamentos sobre o processo necessário de decolonização da teologia cristã almejando uma intelecção da fé que seja pública e engajada nas causas do mundo e do humano.
\end{abstract}

Palavras-chave: Teologia cristã. Direitos humanos. Teoria decolonial. Teologia pública. Teologia decolonial.

\begin{abstract}
In the book If God were a human rights activist, Boaventura de Sousa Santos supports the idea that the dialogue between human rights and progressive theologies provides a good opportunity for the development of intercultural and emancipatory practices (2014, p.113). How can theology contribute to the reconstruction of human rights? Contemporaneity, in all its complexity, demands the construction of a theology that is conscious of the religious and cultural plurality and capable of including in its horizon the socio-religious experiences of the whole of humankind. The task of decolonizing theology and/or of recreating its contents is not only a new object of investigation, but also requires a new kind of theologian, with a new kind of conscience and posture before the current scenario. Searching for tentative answers, this article aims at raising a few points concerning the necessary decolonization process of the Christian theology in order to produce a public intellection of faith that is committed to human and the world's causes.
\end{abstract}

Keywords: Christian theology. Human rights. Decolonial theory. Public theology. Decolonial theology.

Artigo submetido em 22 de maio de 2017 e aprovado em 19 de setembro de 2017.

* Doutor em Teologia Sistemática pela FAJE, pesquisador do grupo de pesquisa Fé e Contemporaneidade do CNPq e, atualmente, bolsista do PNPD da CAPES. Professor no PPG da FAJE e no ISTA e autor de artigos e livros sobre teologia de fronteira numa perspectiva ecumênica e pública. País de Origem: Brasil. E-mail: carlosamc04@gmail.com

Horizonte, Belo Horizonte, v. 15, n. 47, p. 697-718, jul./set. 2017 - ISSN 2175-5841 


\section{Introdução}

O décimo oitavo artigo da Declaração Universal dos Direitos Humanos (DUDH) diz que: "Toda pessoa tem direito à liberdade de pensamento, de consciência e de religião [...]". Interessante como as palavras "pensamento", "consciência" e "religião" estão atreladas ao estado de ser livre. A liberdade para pensar/saber, ser/agir e crer, desde que não prejudique o outro na relação, é fundamental para o desenvolvimento não só do indivíduo, com todas as suas particularidades, mas, sobretudo, para o cidadão que se coloca nos espaços públicos de forma crítica e construtiva.

Revisitar a DUDH depois de 69 anos em que ela foi aceita pela Organização das Nações Unidas (ONU), com o objetivo de discernir a crise da contemporaneidade e propor mudanças, parece ser um bom caminho para a teologia cristã que almeja ter o que dizer/fazer nas culturas plurais da atualidade. A revisitação engajada aos Direitos Humanos pressupõe, por parte da teologia, o compromisso com a construção de um novo mundo possível onde a grande maioria da população mundial deixa de ser objeto de discursos de direitos humanos para ser sujeito (SANTOS, 2014, p.15).

Boaventura de Sousa Santos defende a ideia de que o diálogo entre os direitos humanos e as teologias progressistas é uma boa possibilidade para o desenvolvimento de práticas interculturais e emancipadoras (SANTOS, 2014, p.113). A contemporaneidade com toda a sua complexidade reclama a construção de uma teologia consciente da pluralidade cultural e religiosa capaz de abraçar dentro de seu horizonte as experiências sócio-religiosas do conjunto da humanidade. A tarefa de decolonizar a teologia, e/ou de recriar seu conteúdo, não implica apenas uma novidade no objeto, mas exige também uma novidade no sujeito, ou seja, faz-se necessário um novo tipo de teólogo, com um novo tipo de consciência e postura diante da atualidade.

Horizonte, Belo Horizonte, v. 15, n. 47, p. 697-718, jul./set. 2017 - ISSN 2175-5841 
Como a teologia pode contribuir para a reconstrução da humanidade dos direitos humanos? A partir desta pergunta fundamental, buscamos fazer apontamentos sobre uma teologia decolonial compromissada com os direitos humanos e, ao mesmo tempo, crítica de si mesma. Para este fim, primeiro, acolhemos as interpelações feitas à teologia cristã por Boaventura de Sousa Santos no livro Se Deus fosse um ativista dos direitos humanos. No segundo momento, abordaremos a tarefa pública da teologia e, no terceiro e último momento, elencaremos os desafios para a teologia com uma lógica decolonial.

\section{Deus, teologia e direitos humanos}

Gustavo Gutiérrez, teólogo da libertação, ao falar sobre a teologia como reflexão crítica sobre a práxis, diz que a teologia cristã "deve ser um pensamento crítico de si mesmo, de seus próprios fundamentos” (GUTIÉRREZ, 2000, p.68). Espera-se que uma teologia relevante e libertadora seja capaz de romper com um modelo hegemônico com finalidades massivas e distorções de conteúdo. "O círculo hermenêutico de uma teologia libertada e libertadora deve passar pela suspeita sistemática” (SEGUNDO, 1978, p.252) e ideológica a fim de manifestar até que ponto tal labor teológico é um instrumento de colonização.

Parece ser preocupante o crescente número de movimentos de renovação ("renovaristas", renewalists) que, ao contrário de uma teologia crítica, reforçam modelos hegemônicos neoliberais e expansionistas dotados de uma postura evangelística agressiva e conversionista. No Brasil, tais grupos estão presentes majoritariamente entre os pentecostais e "pseudo-pentecostais"1 que, sem uma formação crítica, cooperam para a intolerância e práticas fundamentalistas. Por exemplo, Edir Macedo, líder da Igreja Universal do Reino de Deus (IURD), escreveu um livreto “A libertação da teologia” em que sugere ao fiel a não se

\footnotetext{
1 "Pseudo-pentecostais" é o nome dado por correntes de sociologia argentina ao tratar sobre o surgimento da Igreja Universal do Reino de Deus e congêneres a partir da década de 1970. Estas igrejas não devem ser compreendidas como "neopentecostais", pois não há elementos em comuns com um novo formato do pentecostalismo clássico. A sua lógica é de mercado e de sucesso. (CAVALCANTI, 2008).
}

Horizonte, Belo Horizonte, v. 15, n. 47, p. 697-718, jul./set. 2017 - ISSN 2175-5841 
envolver com a reflexão crítica e libertadora dos estudos da teologia (MACEDO, 1997). Crente sem formação teológica crítica é sujeito à manipulação ideológica e sofre de raquitismo espiritual.

No início da década de 1970, antes da IURD surgir, Juan Luis Segundo, importante teólogo da teologia da libertação, publicou o livro "Libertação da Teologia” - curiosamente o mesmo título do livro do Macedo, mas com conteúdo completamente diferente -, onde afirma que as "teologias se distinguirão e se oporão metodologicamente ainda que não o queiram nem sejam conscientes disso, segundo a maneira que tiverem de relacionar a mensagem cristã com ideias e condutas massivas ou minoritárias" (SEGUNDO, 1978, p. 248). Teologia digna emerge do compromisso com a criação e com os seres humanos. O seu momento teológico, reflexivo, brota como ato segundo, posterior ao momento pré-teológico, isto é, como resposta aos dilemas por um mundo mais humano, justo e fraterno.

Esse tipo de teologia progressista tem desempenhado durante anos um "papel importante no reforço do inconformismo perante a hipocrisia do pensamento e prática convencional dos direitos humanos" (SANTOS, 2014, p.83). Coisa que a "teologia" (ideologia) da prosperidade, presente nos movimentos de renovação, não tem feito. A sua aproximação com o fiel "é canalizada em processos individualistas, terapêuticos, visando à prosperidade financeira com fim em si mesma" (LIBANIO; CUNHA, 2011, p.92).

Portanto, é a teologia progressista que possibilita um diálogo fecundo com os direitos humanos com o intuito de ações propositivas. Boaventura de Sousa Santos afirma:

que um diálogo entre os direitos humanos e as teologias progressistas é não só possível como provavelmente um bom caminho para desenvolver práticas verdadeiramente interculturais e mais eficazmente emancipadoras. Por meio de um autoenriquecimento mútuo, os direitos humanos e as teologias políticas progressistas podem aprofundar o potencial emancipador de ambos. O resultado será uma ecologia de concepções de dignidade humana, algumas seculares, outras religiosas,

Horizonte, Belo Horizonte, v. 15, n. 47, p. 697-718, jul./set. 2017 - ISSN 2175-5841 
produto daquilo a que noutro lugar chamei hermenêutica diatópica, um exercício de interpretação transformadora, orientada para a prática social e política, entre os topoi dos direitos humanos e os topoi da revelação e libertação das teologias políticas progressistas (SANTOS, 2014, p.113).

A participação de teologias progressistas em fóruns sobre direitos humanos tem sido uma constante. O diálogo entre teologias da libertação e a luta por "outro mundo possível" alimenta engajamentos teológicos contextualizados social e culturalmente. Um exemplo claro dessa relação pode ser visto no surgimento do Fórum Mundial de Teologia e Libertação (FMTL) que, desde 2003, juntamente com o Fórum Social Mundial, insere-se "no novo contexto mundial de sensibilidade ecológica, de pluralismo religioso, de movimentos sociais". (SUSIN, 2006, p.9). O livro Teologia para outro mundo possível, organizado pelo teólogo Luiz Carlos Susin, testifica sobre o esforço da teologia em "contribuir para aprofundar a consciência crítica de pessoas e grupos sociais concretos, oprimidos por formas igualmente muito concretas de relações desiguais de poder" (SANTOS, 2014, p.124). O livro faz um panorama da teologia ao redor do mundo levando em consideração os contextos e propondo reflexões sobre: a) outro mundo possível, b) Deus para outro mundo possível, c) religião para outro mundo possível, e d) teologia para outro mundo possível. Diversos teólogos e teólogas e pesquisadores de áreas afins fazem apontamentos a partir de lugares subalternos.

Santos reconhece a importância de teologias progressistas no fomento da globalização contra-hegemônica, ou globalização a partir de baixo:

Os movimentos sociais e organizações não governamentais (ONGs) que, por meio de articulações locais, nacionais e transnacionais, lutam contra $o$ capitalismo e a opressão colonialista, a desigualdade social e a discriminação, a destruição ambiental e de modos de vida decorrente da voracidade da extração dos recursos naturais, a imposição das normas culturais ocidentais e a destruição das não ocidentais causada ou agravada pela globalização hegemônica (SANTOS, 2014, p.32).

A intelecção da fé que emerge desses espaços é marcada por uma teologia de fronteira. No âmbito cultural, "fronteira" dá a ideia da totalidade dos espaços existentes nas linhas fronteiriças entre os saberes. Segundo Homi Bhabha, as 
regiões fronteiriças são ideais para a construção de identidades porque favorecem a articulação de diferenças culturais num movimento de deslocamento e sobreposição de diferenças. Segundo ele, "esses 'entre-lugares' fornecem o terreno para a elaboração de estratégias de subjetivação - singular ou coletiva - que dão início a novos signos de identidade e postos inovadores de colaboração e contestação" (BHABHA, 2013, p.20). Já na linguagem teológica, o espaço do "entre-lugares", seria como um evento kairótico, em que a esperança do "além" entre os que dialogam, alimenta a expectativa da novidade por outro lugar. "É ser parte de um tempo revisionário, um retorno ao presente para redescrever nossa contemporaneidade cultural; reinscrever nossa comunidade humana, histórica; tocar o futuro em seu lado de cá" (BHABHA, 2013, p.27).

Santos assinala para a importância dos lugares intermediários como espaço ideal para cooperação conjunta (SANTOS, 2014, p.52). Teologias pluralistas e progressistas, que habitam espaços de fronteira, podem "funcionar como uma fonte de energia radical para as lutas contra-hegemônicas dos direitos humanos" (SANTOS, 2014, p.145). E mais:

\begin{abstract}
Desde os anos de 1960 têm vindo a emergir teologias pluralistas e progressistas e práticas religiosas baseadas na comunidade, para as quais Deus se revela no sofrimento humano injusto, nas experiências de vida de todas as vítimas de dominação, opressão ou discriminação e nas lutas de resistência que elas promovem. Como consequência, prestar testemunho a este Deus significa denunciar este sofrimento e lutar contra ele. Tanto a revelação quanto a redenção, ou antes, libertação, têm lugar neste mundo, sob a forma de uma luta por outro mundo possível. Aqui reside a possibilidade de ligar o retorno de Deus a um humanismo transmoderno concreto (SANTOS, 2014, p.112,113).
\end{abstract}

Parafraseando Johann Baptist Metz, o Deus da teologia cristã não é um Deus de conquistadores, mas um Deus dos marginalizados. O cristianismo e a sua teologia deve se despir da roupagem ocidental/colonial e assumir com o empobrecido (social, cultural, financeiramente e etc.) a "luta contra a opressão e o ódio que impedem vastas populações em muitas partes do mundo de se tornar sujeitos e experimentar o mundo como coisa própria” (SANTOS, 2014, p.115).

Horizonte, Belo Horizonte, v. 15, n. 47, p. 697-718, jul./set. 2017 - ISSN 2175-5841 


\section{A tarefa pública da teologia}

Parece estranho abraçar os direitos humanos de forma efetiva a partir de lugares provincianos. Teologias provincianas, de gueto, não dão conta de abarcar os problemas da contemporaneidade. No mundo atual, a teologia estritamente fechada, privada, monoconfessional, está condenada a não ser ouvida e a não ser sequer entendida pela sociedade. Diante da complexidade das culturas contemporâneas, tal teologia se mostra incapaz de dirigir-se à sociedade atual. Não é possível encetar diálogos de qualquer tipo com a opinião pública da sociedade como conjunto e pretender fazê-lo a partir das referências exclusivas de uma religião ou confissão.

O teólogo precisa estar enraizado na fé de uma religião, mas se permanece somente ali ele não estará "à altura daquilo que seu trabalho exige dele. Não estará fazendo teologia no mundo, neste mundo pluralista de hoje; não estará perseguindo a verdade que inclui, mas a que exclui a outros", afirma Paul Knitter (KNITTER, 1985, p.224). Os conteúdos revelados da fé são transmitidos por sujeitos contextualizados. Não existe teologia não inculturada. Ela é sempre um produto humano, inevitavelmente ligado ao paradigma de uma época. A consciência do momento atual é o ponto de partida para mudanças profundas e a irrupção de um novo paradigma teológico que dê conta das demandas dos novos tempos. Em tempos de mudança, a teologia adquire uma nova configuração.

Teologia cristã é pública conforme sua própria pretensão, assinalada pela tradição joanina: "Declarou-lhe Jesus: Eu tenho falado francamente ao mundo; ensinei continuamente tanto nas sinagogas como no templo, onde todos os judeus se reúnem, e nada disse em oculto" (Jo 8,20). A teologia pública está identificada com uma comunidade religiosa, mas não se restringe a ela e, muito menos, busca interesses particulares. Ela milita pelos direitos de todas e todos, independente da tradição religiosa, em busca de condições de vida melhor para os seres humanos e toda criação. 
Não há teologia pública uniforme e monolítica fora e dentro do Brasil. Não há um único significado sobre ela que seja autoritativo e nem uma forma normativa única de fazê-la. Como a definição nunca é uma linguagem vazia ou conceito puro, mas uma construção interpretativa, é imprescindível para a definição da teologia pública perceber quem, por que e a partir de qual lugar socioepistêmico o termo é elaborado. A diversidade de pesquisadores ocupados com o tema trouxe consigo uma diversidade conceitual de modo que não há uma teologia pública universal, mas somente teologias que procuram abordar o âmbito sócio-político dentro de localidades particulares.

Para o teólogo protestante Jürgen Moltmann, a teologia cristã é pública por causa do Reino de Deus. Deve fazê-lo sempre de forma correlativa. Ela deve ser, ao mesmo tempo, conforme a Escritura e contextual. Ela torna-se uma teologia pública, que compartilha os sofrimentos desta época e que formula suas esperanças em Deus no lugar em que vivem os seus contemporâneos. A novidade e diversidade do Reino, que não cabem nas igrejas, exigem que a teologia seja pública (MOLTMANN, 2004, p.17-34).

Já para David Tracy, teólogo católico, que busca relevância da teologia pública na contemporaneidade, toda teologia é um discurso público. Se se pretende mostrar o caráter público de toda teologia, torna-se imperativo estudar primeiro os "públicos" do teólogo. Tracy argumenta que o desafio da teologia sistemática, para demonstrar a publicness (discurso público) da teologia cristã, consiste em gerar, com base na imaginação analógica, uma nova interpretação do evento Cristo, presente nos clássicos religiosos cristãos, ou seja, os grandes textos da tradição cristã baseados na Bíblia (TRACY, 2006, p.513-573).

Moltmann e Tracy nos ajudam a entender as perspectivas que fazem da teologia pública um novo paradigma teológico. Para Moltmann, teologia pública é ser fiel às convicções de fé. Para ser relevante no mundo, a teologia não abre mão da sua confessionalidade. Para Tracy, teologia pública é ser relevante no mundo; é ter o que dizer aos questionamentos da contemporaneidade. Assim, entendemos 
“teologia pública”, não uma disciplina da teologia, mas sua práxis, isto é, sua ação cristã refletida engajada nas causas humanas e ecológicas.

No Brasil, há instituições empenhadas na elaboração da teologia pública². Uma delas é o Instituto Humanitas, órgão transdisciplinar da Unisinos, universidade jesuítica em São Leopoldo - Rio Grande do Sul, que organiza anualmente simpósios, publica livros e artigos sob o título de “Teologia Pública”. O Instituto define teologia pública como:

O Programa Teologia Pública propõe-se a abrir e articular novas possibilidades de engajamento da teologia no âmbito acadêmico e sociocultural propondo uma Teologia que participa ativamente nos debates que se desdobram na esfera pública da sociedade e da academia e explicitando a relevância pública da teologia e da fé cristã. Nessa perspectiva busca articular a reflexão teológica em diálogo com as ciências, culturas e religiões, de modo interdisciplinar e transdisciplinar, atenta aos desafios e possibilidades que se apresentam na vida social, política, econômica e cultural da sociedade, bem como na vida eclesial, hoje. ${ }^{3}$

Voltada para a comunidade universitária, mas não restrita a ela, a teologia pública proposta pelo Instituto busca contribuir para o debate da relevância da transcendência na construção de uma sociedade justa e igualitária. No decorrer da modernidade, a teologia se tornou cada vez mais restrita aos muros eclesiais e destinada ao consumo interno dos sujeitos religiosos. Seu caráter acadêmico e público perdeu visibilidade, enquanto as ciências positivistas ganharam força e se institucionalizam no âmbito das universidades, nas suas mais variadas especializações e aplicações técnicas. Mesmo admitindo certa legitimidade ao religioso, enquanto opção individual inscrita no âmbito dos valores que não devem interferir no exercício da razão, a comunidade científica dispensou a teologia de suas buscas e atividades interdisciplinares. Assim, a teologia se refugiou no exílio sem ter o que dizer ao sujeito dotado de uma razão técnico-científica. Ela se

\footnotetext{
${ }^{2}$ Além do Instituto Humanitas (Unisinos), destacamos também o grupo de pesquisa em teologia pública do PPG em Teologia da Escola Superior de Teologia (EST) que, desde 2007, articula estudos sobre o tema; a elaboração de estudos nos grupos temáticos dos congressos da Sociedade de Teologia e Ciências da Religião (SOTER) e da Associação Nacional dos Programas de Pós-Graduação em Teologia e Ciências da Religião (ANPTECRE).

${ }^{3}$ Sobre a definição de "teologia pública" no site do IHU (2017).
}

Horizonte, Belo Horizonte, v. 15, n. 47, p. 697-718, jul./set. 2017 - ISSN 2175-5841 
encontrava em uma situação paradoxal, em termos de sua legitimidade epistemológica.

A teologia sai do exílio quando a crítica bate às portas da pretensão objetivista e empirista da concepção positivista da ciência. A suspeita hermenêutica e ideológica questiona a experiência científica moderna mostrando a incapacidade da apropriação de um dado puro. Todo dado é interpretado e mediado pela linguagem. Além disso, a suspeita ideológica revelou que todo conhecimento reflete interesse. Assim, a concepção positivista de ciência começa a ruir. Por revelar visão interessada, absoluta e apodítica, torna-se equivocada (CUNHA, 2016, 240-41).

Nesse cenário, a teologia sai da periferia e retorna à praça pública onde acontecem as grandes discussões existenciais. Ela retoma a sua condição como ciência da intelecção da fé capaz de dialogar com o mundo. Para isso, propõe-se a abrir novas possibilidades de engajamento da teologia no âmbito acadêmico e sociocultural, caracterizando-a como teologia pública.

Os problemas e desafios dos Direitos Humanos são problemas e desafios da teologia também. Caso contrário, a teologia deixa de ter relevância pública e perde o seu sentido de ser. É empobrecedor para a intelecção da fé ficar restrita aos muros eclesiais envolvida somente com as demandas das Igrejas. A função da teologia não se restringe ao âmbito intraeclesial, pois a Igreja não existe para si mesma. Igreja, ekklesia, palavra grega composta pelo prefixo "ek”, dá ideia de movimento para fora: "reunião", "assembleia” ou "congregação", voltada para fora. A Igreja é essencialmente missionária, de portas abertas, voltada para o mundo, em sintonia com as necessidades concretas da vida das pessoas e em obediência à missão de Deus, missio Dei.

Essa missão, na perspectiva da teologia do diálogo inter-religioso, não se faz por meio de "oposições”, acentuando as diferenças e reforçando colonizações do ser, do pensar e do poder. O diálogo entre as religiões abre não só a possibilidade de legitimação de cada cultura e da sua tradição de fé como propõe novos modelos 
de missão. No novo jeito de fazer missão, “de posição”, o cristianismo e a teologia deveriam se posicionar junto a outras religiões no esforço de recuperar a humanidade dos direitos humanos (SANTOS, 2014, p.113).

A ideia de "salvação", que emerge da teologia do "ecumenismo mais ecumênico” (Raimon Panikkar), não está limitada a redenção da alma do ser humano, como afirma alguns segmentos da antropologia teológica dicotômica ou tricotômica. Na tradição judaico-cristã, o ser humano é um ser integral, indivisível. A salvação abarca também a realidade material, física e corporal, das mulheres e dos homens e toda criação. Empenhar-se pela salvação da humanidade significa lutar por seus direitos, pela sua dignidade, por sua libertação e cura. Este é um elemento em comum entre as religiões. Num sentido geral: religiões de salvação. Segundo Claude Geffré:

Religiões de salvação, no sentido de estarem à busca de uma libertação em relação ao que é o limite do eu ou o limite do mundo das aparências em contraste com a Realidade última. Portanto, toda atitude religiosa autêntica coincide com um certo descentramento de si mesmo em proveito de uma Realidade última, quer seja ela apreendida com um Ser pessoal, como o Deus de Israel, o Deus Trindade ou Alá, ou através do conceito de Absoluto, de Vazio ou de Tao (GEFFRÉ, 2004, p.151).

A teologia pública é portadora de uma inteligência aberta, disposta a refazer os seus próprios conteúdos quando interpelada pelos dilemas da humanidade. Não é uma teologia cristã divorciada da vida concreta das pessoas, mas preocupada com a relevância das boas novas de Jesus Cristo na realidade dos seres humanos de hoje. Não há espaço nesse tipo de intelecção da fé para formulações dogmáticas indispostas a redizer para a atual geração o valor da substância visada nos símbolos da fé e a formulação cultural do dogma e da tradição4.

\footnotetext{
${ }^{4}$ Importante dizer que as palavras "dogma" e "tradição" são positivas, abertas e polissêmicas. Já os extremos dos termos, dogmatismo e tradicionalismo, são termos negativos e apontam para a mumificação do dogma e da tradição.
}

Horizonte, Belo Horizonte, v. 15, n. 47, p. 697-718, jul./set. 2017 - ISSN 2175-5841 


\section{Descolonizando a teologia}

Além da sua tarefa pública, a teologia deve ser crítica de si mesma para manter o foco nos processos libertadores do mundo todo. Caso contrário, ela só reforça a condição de estar atrelada a um tipo de cristianismo contido nas cinco ideologias da modernidade/colonialidade. As outras são liberalismo, marxismo, conservadorismo e colonialismo (MIGNOLO, 2007, p.34). A libertação da teologia acontece quando ela se submete ao exercício libertador das suas ideias e métodos arcaicos próprios de uma intelecção da fé encerrada em sua torre de marfim. Remexer a base da teologia cristã, a partir das demandas do mundo contemporâneo e exigir que ela tenha uma palavra/ação efetiva, parece ser fundamental para uma teologia que anseia ser contextual. Para isto, Juan Luis Segundo propõe um exercício de libertação da teologia: primeiro, a suspeita ideológica; segundo, aplicação da suspeita a toda superestrutura e à teologia; terceiro, nova maneira de experimentar a realidade teológica levando à suspeita exegética e, quarto, uma nova hermenêutica. Quatro momentos importantes de um círculo hermenêutico para uma teologia livre e libertadora que passa pela "suspeita sistemática de que tanto a teologia vivida, como sua expressão acadêmica, têm sido desviadas para finalidades massivas, com sua correspondente distorção de conteúdos (SEGUNDO, 1978, p.252).

A consciência da decolonização da teologia cristã na atualidade é fruto do pós-colonialismo que, a partir da metade do século $\mathrm{XX}$, empenha-se na independência, libertação e emancipação das sociedades exploradas pelo imperialismo e neocolonialismo, especialmente nos países do sul global. Associado com os estudos pós-estruturais, desconstrutivistas e pós-modernos, o póscolonialismo propõe uma "epistemologia crítica às concepções dominantes da modernidade" (COSTA, 2006, p.83-84) ao identificar uma relação antagônica entre o colonizado e o colonizador. 
A percepção dessa relação de colonização e exploração atravessou várias áreas do saber, inclusive a teologia. "Mesmo que não linear, disciplinado e articulado, o argumento pós-colonial em toda sua amplitude histórica, temporal, geográfica e disciplinar percebeu a diferença colonial e intercedeu pelo colonizado” (BALLESTRIN, 2013, p.91). A produção de reflexões a partir do colonizado nos livros Retrato do colonizado precedido de retrato do colonizador (1947), de Albert Memmi, Discurso sobre o colonialismo (1950), de Césaire, Os condenados da terra (1961), de Franz Fanon, Orientalismo (1978), de Edward Said e Pode o subalterno falar? (1988), de Gayatri Spivak foram seminais na intercessão pelos colonizados e contribuíram para uma transformação epistemológica das ciências sociais.

Os Grupos de Estudos Subalternos que daí surgiu, tanto no sul da Ásia, África e América Latina, reforçavam o pós-colonialismo como um movimento epistêmico, intelectual e político contra-hegemônico e na legitimação das culturas subalternas. O documento do Grupo Latinoamericado de Estudos Subalternos (1998) dá uma noção da proposta:

O trabalho do Grupo de Estudos Subalternos, uma organização interdisciplinar de intelectuais sul-asiáticos dirigida por Ranajit Guha, inspirou-nos a fundar um projeto semelhante dedicado ao estudo do subalterno na América Latina. $\mathrm{O}$ atual desmantelamento dos regimes autoritários na América Latina, o final do comunismo e o consequente deslocamento dos projetos revolucionários, os processos de democratização, as novas dinâmicas criadas pelo efeito dos meios de comunicação de massa e a nova ordem econômica transnacional: todos esses são processos que convidam a buscar novas formas de pensar e de atuar politicamente. Por sua vez, a mudança na redefinição das esferas política e cultural na América Latina durante os anos recentes levou a vários intelectuais da região a revisar epistemologias previamente estabelecidas nas ciências sociais e humanidades. A tendência geral para uma democratização outorga prioridade a uma reconceitualização do pluralismo e das condições de subalternidade no interior das sociedades plurais (Grupo Latinoamericano de Estudos Subalternos apud BALLESTRIN, 2013, p.94).

$\mathrm{Na}$ década de 1990, surge, nos Estados Unidos, o Grupo Modernidade/Colonialidade (Grupo M/C) formado por intelectuais latino- 
americanos e americanistas 5 inspirados nas reflexões dos Grupos de Estudos Subalternos. O Grupo M/C aos poucos vai sendo estruturado sob a inspiração de teóricos, dentre eles o sociólogo peruano Aníbal Quijano para quem a modernidade oculta a colonialidade, isto é, atrás da "modernidade”, do discurso da salvação, do progresso, da modernização e do bem comum está a lógica colonial encoberta impondo o controle, a dominação e a exploração. Segundo Quijano, não existe modernidade sem colonialidde (QUIJANO, 2000, p. 342-386). Além do pensamento de Quijano, o Grupo M/C

Encontrou inspiração em um amplo número de fontes, desde as teorias críticas europeias e norte-americanas da modernidade até o grupo sulasiático de estudos subalternos, a teoria feminista chicana, a teoria póscolonial e a filosofia africana; assim mesmo, muitos de seus membros operaram em uma perspectiva modificada de sistema-mundo. Sua principal força orientadora, no entanto, é uma reflexão continuada sobre a realidade cultural e política latino-americana, incluindo o conhecimento subalternizado dos grupos explorados e oprimidos (ESCOBAR, 2003, p.53).

Segundo Ramón Grosfoguel, a colonialidade se reproduz em uma tripla dimensão: a do poder, do saber e do ser impondo "a continuidade das formas coloniais de dominação após o fim das administrações coloniais, produzidas pelas culturas coloniais e pelas estruturas do sistema-mundo capitalista moderno/colonial" (GROSFOGUEL, 2008, p.126). Os povos periféricos nãoeuropeus e não-estadunidenses, ainda que não estejam sujeitos a uma administração colonial, vivem numa situação colonial imposta por países e agências que detêm o poder. É o caso das intervenções dos Estados Unidos, do Fundo Monetário Internacional, do Banco Mundial, do Pentágono e da OTAN sobre os países “subdesenvolvidos”.

Além das críticas políticas, econômicas e sociais feitas pelo Grupo M/C, há também a crítica à geopolítica do conhecimento - tema recorrente no Grupo e

\footnotetext{
${ }^{5}$ Podemos destacar Aníbal Quijano, Enrique Dussel, Walter Mignolo, Immanuel Wallertein, Santiago Castro-Gómez, Nelson MaldonadoTorres, Ramón Grosfóguel, Edgardo Lander, Arthuro Escobar, Fernando Coronil, Catherine Walsh, Boaventura Santos, Zulma Palermo entre outros.
}

Horizonte, Belo Horizonte, v. 15, n. 47, p. 697-718, jul./set. 2017 - ISSN 2175-5841 
motivo de separação dos Grupos de Estudos Subalternos. Mignolo critica o “imperialismo" dos estudos pós-coloniais e subalternos por não provocarem uma ruptura com o referencial teórico de autores eurocêntricos (MIGNOLO, 1998). É preciso um "giro decolonial” (Nelson Maldonado-Torres) proposto pelos estudos descoloniais como resistência teórica e prática, política e epistemológica, à lógica da modernidade/colonialidade.

Mignolo aponta para a emergência de novos lugares de enunciação, uma “gnose liminar" que é expressão de uma razão subalterna lutando para afirmação dos saberes historicamente subalternizados. Para ele, estamos vivendo a emergência de um "outro pensamento", um pensamento liminar que aponta para uma razão pós-ocidental. Essa gnose ou pensamento liminar é uma reflexão crítica sobre a produção do conhecimento e implica na sua redistribuição geopolítica até então pautada na colonização epistêmica e na subalternização de todas as formas de saberes, povos e culturas que não estivessem pautadas nos cânones da ciência eurocêntrica.

O deslocamento do lócus de enunciação dos centros do sistema modernocolonial para suas margens, para as fronteiras das diferentes histórias locais não significa negar a importância da ciência e das formas de saberes ocidentais hegemônicas. Não se trata também de um relativismo cultural e epistêmico. Esses projetos não são universais e abstratos, mas circunscritos nos limites das diferenças coloniais específicas na formação do sistema-mundo moderno colonial.

Mignolo diz que reconhecida a colonialidade, feita a crítica a partir da sua perspectiva, o próximo passo indispensável é o que Quijano chama de “desprendimiento" e que Mignolo batiza de “delink”, uma tradução para o inglês do termo utilizado em espanhol e que atribuiu a seu projeto de mudança epistemológica. Para o nosso semiótico, foi no campo epistemológico que a retórica da modernidade ganhou força por produzir e reproduzir discursos e narrativas que justificam a colonialidade. 
Mignolo defende a decolonização epistêmica, isto é, ela se desvincula dos fundamentos genuínos dos conceitos ocidentais e da acumulação de conhecimento. O desvinculamento epistêmico não significa abandono ou ignorância do que já foi institucionalizado por todo o planeta, mas um aprender a desaprender:

Decolonização (da mente) deve revelar o totalitarismo da cumplicidade da retórica da modernidade e a lógica da colonialidade, a fim de abrir espaço para a possibilidade [...] de "outro mundo", em que muitos mundos coexistirão (MIGNOLO, 2007b, p.469).

A decolonização pressupõe o que Mignolo chama de border thinking como espaço fronteiriço entre a diversidade das histórias subalternas e suas correspondentes subjetividades, isto é, o pensamento deve vir das margens. Apoiado no conceito de transmodernidade cunhado por Enrique Dussel, Mignolo afirma que a crítica deve vir não só de fora, mas da exterioridade: "onde a diferença entre o 'espaço da experiência' e entre 'o horizonte da expectativa' torna-se aparente" (MIGNOLO, 2007, p.494).

A gnose liminar enquanto conhecimento é produzida na interseção dos colonialismos modernos e do conhecimento produzido na perspectiva das modernidades coloniais. Uma forma de conhecimento construído nos espaços liminares, nas fronteiras da diferença colonial, uma poderosa e emergente gnoseologia que, na perspectiva do subalterno, está deslocando e absorvendo as formas hegemônicas do conhecimento. Não se trata de sincretismo e nem de hibridismo, mas uma maneira de ser e de existir de todos aqueles que habitam a fronteira:

Quem habita a fronteira do lado da colonialidade "sente", cedo ou tarde, a diferença colonial. A questão é o que fazemos uma vez que estamos conscientes? Há três caminhos possíveis: tentamos nos assimilar, e boa sorte na assimilação; nos adaptamos o melhor que podemos, pois temos que viver; ou, a terceira, nos adaptamos e começamos a construir projetos que apontam para outras formas de vida. Neste momento a consciência e o ser de fronteira transformam-se no pensamento fronteiriço em ação, colocamos a experiência e o pensamento em ação. Alguns chamam isto de pensamento [ou posicionamento] crítico fronteiriço. O “crítico" está sobrando porque o pensamento fronteiriço em ação é necessariamente 
crítico e decolonial e distingue-se da teoria crítica da Escola de Frankfurt (MIGNOLO, 2013). ${ }^{6}$

A teoria da decolonialidade é tanto um discurso crítico que traz para o primeiro plano o lado colonial do sistema mundial moderno e a colonialidade do poder embutida na própria modernidade, quanto um discurso que altera a proporção entre os locais geohistóricos e a produção de conhecimentos. A relação entre a localização geográfica e localização epistêmica assinalam como essa relação é estabelecida pela diferença colonial e colonialidade do poder.

O pensamento decolonial demanda o fazer decolonial, isto é, um giro com a pretensão de substituir a geopolítica de Estado de conhecimento de seu fundamento na história imperial do Ocidente dos últimos cinco séculos, pela geopolítica de Estado de pessoas, línguas, religiões, conceitos políticos e econômicos, subjetividades, etc., que foram negadas. Tal comprometimento propõe: a) desvelar a lógica da colonialidade e da reprodução da matriz colonial do poder; e b) desconectar-se dos efeitos totalitários das subjetividades e categorias de pensamento ocidentais.

Retomando o argumento de Boaventura de Sousa Santos no livro Se Deus fosse um ativista dos direitos humanos, a saber, que o "diálogo entre os direitos humanos e as teologias progressistas é não só possível como provavelmente um bom caminho para desenvolver práticas verdadeiramente interculturais e mais eficazmente emancipadoras" (SANTOS, 2014, p.113), vamos além e reforçamos que isto é possível desde que tais teologias assumam uma lógica decolonial.

A teologia decolonial é desafiada a refundar o seu processo educacional com a necessidade de ouvir atentamente o clamor dos direitos humanos problematizando as dinâmicas socioculturais e geopolíticas contemporâneas e deixando transparecer os processos de colonização. A epistemologia que daí advém questiona os mecanismos hegemônicos e, ao mesmo tempo, dá voz à pluralidade de

${ }^{6}$ Cf. A entrevista de Walter Mignolo: Decolonialidade como o caminho para a cooperação, (MIGNOLO, 2013).

Horizonte, Belo Horizonte, v. 15, n. 47, p. 697-718, jul./set. 2017 - ISSN 2175-5841 
construções do conhecimento. A consciência da articulação entre os saberes nos espaços fronteiriços é condição de possibilidade para novas relações nos vários níveis da realidade.

A partir da crítica decolonial, Nicolas Panotto assinala três atitudes frente a situação da educação teológica na América Latina: a) Uma atitude de profunda honestidade com respeito a situação de crise da matriz colonial que persiste em nossas instituições e discursos, b) uma atitude de genuína sensibilidade para discernir a pluralidade de vozes e formas alternativas de ser, fazer, dizer e pensar e como isso se articula com novas epistemologias, c) uma atitude de ação intencional que logre mudanças profundas para que os espaços tradicionais de educação teológica empoderem as vozes emergentes (PANOTTO, 2016, p.7).

A partir dessas atitudes, Juan José Tamayo chama a atenção para novos horizontes para a elaboração de uma teologia decolonial: a) Intercultural, na elaboração de uma teologia intercultural em diálogo simétrico entre culturas; b) Inter-religioso, da superação da religião única, colonizadora, para o pluralismo religioso a partir das vítimas e com a prática da libertação; c) Hermenêutico, da libertação do discurso religioso fundamentalista, implicando a passagem da teologia como mera exegese de textos para uma teologia hermenêutica em busca de sentido; d) Feminista, questionadora do caráter patriarcal das crenças e da estrutura androcêntrica da teologia para a elaboração de reflexões teológicas empoderadas; e) Ecológico, rompendo com a teologia antropocêntrica, que legitima o modelo de desenvolvimento científico-técnico da modernidade, para uma ecoteologia da criação. No lugar da exploração, o cuidado; f) Ético-moral, a caridade como ato primeiro do labor teológico. A teologia tem uma razão prática. É preciso resgatar os processos históricos a partir dos novos sujeitos: mulheres marginalizadas, etnias e raças subjugadas, culturas subalternas, religiões sufocadas, povos, países e continentes presos pelo lado oculto da globalização neoliberal; g) Da esperança, para além da utopia dos esforços políticos presentistas; h) Simbólico, questionando o absolutismo despótico em que incide, às 
vezes, a linguagem dogmática e recuperando o símbolo como a linguagem mais própria das religiões e da teologia; i) Da sexualidade, as questões sobre a homossexualidade e sobre gênero interpelando a teologia cristã a se desinstalar do seu espaço heterossexual, patriarcal e machista para pensar outras possibilidades e etc. (TAMAYO, 2006, p.444-450).

Os horizontes apontados por Tamayo são fontes inesgotáveis de reflexão teológica empenhada na construção dos direitos humanos. Explorá-los, um por um, é uma obrigação da teologia intercultural e pertinente. Atualmente, há teólogas e teólogos empenhados em tais projetos. São esforços minoritários, mas eficientes. O desafio é enorme para a teologia cristã. Dissemos que a teologia tem uma configuração pública, portanto, transita entre e a partir da igreja, da academia e da sociedade. Tem sido relativamente fácil para a teologia mobilizar instâncias acadêmicas e sociais rumo ao projeto decolonial. Já com relação à igreja, "a casa do teólogo" (Paul Tillich), não podemos dizer o mesmo.

\section{Conclusão}

A pergunta fundamental norteadora da nossa reflexão foi: como a teologia pode contribuir para a reconstrução da humanidade dos direitos humanos? Para respostas aproximativas e inconclusas, mostramos, a partir das interpelações colocadas no livro Se Deus fosse um ativista dos direitos humanos de Boaventura de Sousa Santos, que a teologia cristã precisa assumir a sua tarefa pública no esforço de reconhecer os seus interlocutores para ter o que dizer/fazer na contemporaneidade. Teologias cristalizadas pelo tradicionalismo e pelo dogmatismo não dão conta dessa tarefa e, pior, "teologias" (ideologias) da prosperidade dotadas de uma consciência alienada reforçam o estado de colonização e opressão, principalmente sobre os excluídos.

Além da teologia progressista, de tarefa pública, a intelecção da fé necessita de uma lógica decolonizadora, que lhe remexa as bases revelando a ontologia 
colonial e propondo ações de empoderamento. A opção pelo empobrecido pela colonialidade do poder, do saber e do ser, nos lugares subalternos, passa a ser na atualidade o lócus ideal para teologias decoloniais. Os horizontes de reflexão e ação são amplos e desafiadores.

Uma teologia cristã que assume o seguimento de Jesus Cristo testemunha ao mundo a sua vocação. Expressão disso se encontra na Constituição Pastoral Gaudium et spes, do Concílio Vaticano II: "Cristo manifesta plenamente o homem ao próprio homem e lhe confere a sua altíssima vocação” (GS 22). A divinização do ser humano no Deus-homem leva a humanização ao ápice.

A atuação de Jesus visa promover e acolher o governo do Pai: provocar a consciência da liberdade de filhos e filhas, construir a sociedade justa, curar doenças e enfermidades, libertar do mal, dar ânimo e purificar a religião. O Reino não é algo etéreo. O convite de acolher e "entrar" na dinâmica do Reino implica conversão profunda e deixar-se ser transformado e transformar a vida tal como Deus a quer.

Aqueles que se associam ao projeto da implantação do "governo divino" não podem permanecer à mercê de um sistema que aliena e oprime o ser humano. "Não podeis servir a Deus e ao Dinheiro" (Mt 6,24). Jesus introduziu novo modelo de comportamento social. Não é possível entrar no Reino de Deus sem sair do reino das riquezas (Mamon). A mudança de vida em prol do bem de toda criação é característica do cidadão do Reino de Deus. Jesus anunciou o Reino do Pai: a transformação radical deste mundo segundo o projeto libertador de Deus. Onde há justiça, liberdade e amor, aí estão as sementes do Reino. O teólogo cristão, discípulo de Cristo, não tem outro compromisso senão com o Espírito que nos anima na direção dessa esperança. 


\section{REFERÊNCIAS}

BALLESTRIN, Luciana. América Latina e o giro decolonial. Revista Brasileira de Ciência Política, Brasília, n. 11, p. 89-117, maio-agosto 2013.

BHABHA, Homi. O local da cultura. 2.ed. Belo Horizonte: Ed. UFMG, 2013.

CAVALCANTI, Robinson. Pseudo-pentecostais: nem evangélicos, nem pentecostais. Revista Ultimato, Viçosa: Ed. Ultimato, ano XLI, n. 314, p.36-37, set./out. 2008.

COSTA, Sérgio. Dois Atlânticos: teoria social, anti-racismo e cosmopolitismo. Belo Horizonte: Editora UFMG, 2006.

CUNHA, Carlos. Paul Tillich e a teologia pública no Brasil. São Paulo: Garimpo Editorial, 2016.

ESCOBAR, Arthuro. Mundos y conocimientos de otro modo: el programa de investigación modernidad/colonialidad latinoamericano. Tabula Rasa, Bogotá, n. 1, p. 58-86, 2003.

GEFFRÉ, Claude. Crer e interpretar: a virada hermenêutica da teologia. Petrópolis: Vozes, 2004.

GROSFOGUEL, Ramón. Para decolonizar os estudos de economia política e os estudos pós-coloniais: transmodernidade, pensamento de fronteira e colonialidade global. Revista Crítica de Ciências Sociais, Coimbra, n. 80, p. 115-147, 2008.

GUTIÉRREZ, Gustavo. Teologia da libertação: perspectivas. São Paulo: Loyola, 2000.

Instituto Humanitas Unisinos - IHU. Disponível em:

<http://www.ihu.unisinos.br/areas/teologia-publica/58627-programa-teologia-publica>. Acesso em: 6 abr. 2017.

KNITTER, Paul. No Other Name? Maryknoll: Orbis, 1985.

LIBANIO, J.B.; CUNHA, Carlos. Linguagens sobre Jesus: as linguagens tradicional, neotradicional pós-moderna, caristmática, espírita e neopentecostal. vol.1. São Paulo: Paulus, 2011.

MACEDO, Edir. A libertação da teologia. Rio de Janeiro: Universal, 1997.

MIGNOLO, Walter. A entrevista de Walter Mignolo: Decolonialidade como o caminho para a cooperação. 2013. Entrevista concedida a Luciano Gallas. Tradução: André Langer. Disponível em:

<http://www.ihuonline.unisinos.br/index.php?option=com_content\&view=article\&id=52 $53 \&$ secao $=43>$. Acesso em: 6 abr. 2017.

MIGNOLO, Walter. La idea de América Latina. La herida colonial y la opción decolonial. Barcelona: Gedisa, 2007. 
MIGNOLO, Walter. Delinking. The rethoric of modernity, the logic of coloniality and the grammar of de-coloniality. Cultural studies, Andover, v. 21, n. 2 e 3. Routledge. 2007b.

MIGNOLO, Walter. Postoccidentalismo: el argumento desde América Latina, In: CASTROGÓMEZ, Santiago; MENDIETA, Eduardo (coords.). Teorías sin disciplina:

latinoamericanismo, poscolonialidad y globalización en debate. México: Miguel Ángel

Porrúa, 1998.

MIGNOLO, Walter; TLOSTANOVA, Madina. Learning to Unlearn: Decolonial Reflections from Eurasia and the Americas. Ohio State University Press, 2012.

MOLTMANN, Jürgen. Experiências de reflexão teológica: caminhos e formas da teologia cristã. São Leopoldo: Unisinos, 2004.

PANOTTO, Nicolás. Descolonizar la educación teológica: hacia una ecología de saberes teológicos en América Latina. Conferencia presentada el II Congreso de Estudios Postcoloniales. 2016, p.7.

QUIJANO, Aníbal. Colonialidad del poder y clasificación social. Journal of worldsystems research, Colorado, v. 11, n. 2, 2000, p. 342-386.

SANTOS, Boaventura de Sousa. Se Deus fosse um ativista dos direitos humanos. 2.ed. São Paulo: Cortez, 2014.

SEGUNDO, Juan Luis. Libertação da teologia. São Paulo: Loyola, 1978.

SUSIN, Luiz Carlos (Org.). Teologia para outro mundo possível. São Paulo: Paulinas, 2006.

TAMAYO, Juan José. Teologia para outro mundo é possível. In: SUSIN, Luiz Carlos (Org.). Teologia para outro mundo possível. São Paulo: Paulinas, 2006, p.437-453.

TRACY, David. A imaginação analógica: a teologia cristã e a cultura do pluralismo. São Leopoldo: Unisino, 2006. 